\title{
Personal Names and German Noun Inflection
}

\author{
HERBERT PENZL
}

\section{CASE FORMS OF PERSONAL NAMES (IN OHG, MHG, NHG)}

M

ost proper nouns can morphologically and semantically be derived from common nouns. They often show, however, special developments in lexicon, phonology, morphology, and syntax. Odo Leys (1966) called this their "lexikalische Versteinerung" and "phonologische Versteinerung." We find among personal nouns various compound-types no longer productive; we find lexically, e.g. designations of trades and professions no longer part of the vocabulary. Proper nouns sometimes preserved reflexes of dialectal or phonotactic sound changes which never were adopted into the standard language. Syntactically, the use of the articles has special rules among proper names. Also the morphology of names shows special featues, not shared by common nouns. In this paper ${ }^{1}$ I want to discuss some peculiarities of the inflection of personal names in German.

All periods of the German language show differences in the inflection of proper nouns and common nouns. The two main types of German noun inflection, the so-called strong and the weak $(n$-) declensions, are found in the inflection of proper nouns and common nouns. In Old High German (OHG) we find accusative forms of strong masculine names with an adjectival ending: Hartmuotan, Werinbrehtan, Hludowigan, even including foreign nouns like Abrahaman (Tatian 131, 25), Petrusan (Tatian $220,2)$. Thus the nominative, the case of the subject, and the accusative, the case of the direct object, are clearly differentiated. Common nouns like muot 'mood,' wig 'battle' do not distinguish between these two cases. Strong feminine names in -drud, -frit (-frid), -gart, -gund, -heit, -hild, (hilt), -munt, -muot, etc., keep their endingless nominatives; thus the

'This paper is a revised version of one, entitled "Personennamen und deutsche Grammatik im 18. Jahrhundert", read at the XIIIth International Congress of Onomastic Sciences in Cracow, Poland, August $21-25,1978$. The congress had as its motto "Nomina appellativa et nomina propria." 
nominative Brunihild is kept apart from the genitive and accusative Brunihilda. $^{2}$

In Middle High German (MHG) strong masculines like Sifrit, Gernot take weak accusative endings in -en, Sifriden, Gernoten, thus keeping nominative and accusative apart. Also strong feminine names like e.g. Kriemhilt differentiate nominative and oblique forms (Kriemhilde) unlike the common nouns of the same type (MHG gebe all sing.) (cf. Paul Moser-Schröbler 1969, §133)

"Weak" MHG masculine and feminine nouns mark the nominative singular, specially in comparison to all other cases: MHG bote 'messenger,' zunge 'tongue' versus all oblique and plural forms boten, zungen. In New High German (NHG) the feminines (zunge) became strong in the singular; most of the weak masculines joined the strong group as well by introducing $n$ from the oblique cases into the nominative: MHG brunne 'well' became Brunnen (gen. Brunnens), MHG garte became Garten (gen. Gartens). Only words designating humans or animals remained weak, thus marking the nominative versus all oblique cases: Bote (oblique, plural Boten), also Hase (obl., pl. Hasen) 'hare,' Knabe 'boy,' Erbe 'heir,' etc.

Not only the distinction between the case of the subject, which is also used as the call form ('vocative' in Latin), and the cases of objects, is particularly important with personal names, also the marking of the case indicating possession and other attributive relations, the genitive. In Modern German the feminine names have masculine genitive endings: e.g. - $s$ in Hildes, Maries, Gertruds like Ludwigs, Peters, Karls. Common nouns have -es instead of $-s$ after a sibilant, e.g. Satzes 'of the sentence,' Halses, Wunsches, but personal names with their less predictable nominative form do not have genitive forms like *Fritzes, *Heinzes, *Maxes, because they would imply family names like Fritze, Heinze and a feminine Maxe. According to Duden (1973, \#455) the choice here would be between merely graphic Fritz', e.g. in Fritz' Hut 'the hat of Fritz,' or a phrase like der Hut von Fritz. Des Fritz with the article preceding the first name is not considered standard language ("hochsprachlich"; cf. also Duden 1973, \#375) but des Horaz Satiren, die Dramen des Sophokles is “correct." Genitives like Fritzens, Heinzens, Maxens with -ens, a combination of the weak genitive ending -en and strong $-s$, are labelled "altertümlich" ('archaic') by Duden. Only a very small number of masculine common nouns with side-forms in $-e$ and $-e n$ in the nominative 
have -ens in the genitive: Name(n), gen. Namens, Friede(n), gen. Friedens, and one neuter Herz, gen. Herzens.

\section{CASE FORMS IN ENHG AND THE 18th CENTURY}

Most scholars recognize a transitional period between Middle High German (MHG) and New (Modern) High German (NHG) in the history of the German language (Penzl 1982, §2), which they call Early New High German (ENHG, "Frühneuhochdeutsch') and most handbooks date between 1350 and 1650 . A better terminal date seems 1700 or 1720 , if the establishment of an essential nonregional standard written language is taken as the main criterion. The earliest writers of complete grammars of German in the 16th century, Laurentius Albertus (1573), ${ }^{3}$ Albert Ölinger (1573), Johannes Claujus (1578) do not mention any difference in the declension of proper nouns and common nouns, althought they are aware of their typological distinction. Clajus (Weidling 1894, p. 21) writes: "Nomen aliud est Proprium, aliud Appellatiuum." 4 In their paradigms of strong and weak feminine commons nouns, nominative and accusative are given as identical: die fraw 'domina,' die farb; die Lade 'cista,' die Hand, die Stunde (Clajus p. 48). The grammarians (cf. Jellinek 1914, § $387)$ do not mention that names kept the $-(e) n$ ending in the accusative singular. The MHG distinction Kriemhilt, oblique Kriemhilde, is not attested in ENHG because of the regular loss of final - $e$ (ENHG apocope) in most dialects. The texts show clear distinction between nominative, genitive, and accusative (dative) forms. In Heinrich Wittenweiler's epic Der Ring (1400), e.g. one main character's name Pfertschi has the genitive Pfertschis, accusative Pfertschin (Penzl 1982, §220). Joseph Kehrein's (1854) data show many examples of the inflection of personal names: Carl, gen. Carls, Carlen, Carlens; Albrecht, accus. Albrechten; Eva, gen. Evens, Marie, gen. Marien, etc. Within the same paradigm strong and weak case endings are used; this results in maximal case distinctions with personal names.

What is the state of affairs in the 18th century when we no longer encounter the great regional distinctions of the ENHG period? (cf. Bach 1952 , vol. 1.1, §47). The declension of names may lack dialectal isoglosses but it clearly follows the pattern established in the ENHG period.

\footnotetext{
${ }^{3}$ Müller-Fraureuth (1895), p. 5: "Proprium et Appellatiuum est: Propria indiuiduis singulariter applicantur, ut discernantur a rebus alijs ...".

${ }^{4}$ Clajus adds that proper nouns can be personal names (Johannes, Anna), names of cities (Leipzig), islands (Malta), mountains (der Hundsberg), rivers (die Wipper).
} 
The descriptions in the 18th century grammars of German show this; the authors on the whole describe their own usage, e.g., in the grammars by S. Hentschel (1729), C.F. Aichinger (1753), J.S.V. Popowitsch (1754), I. Weitenauer (1764), J. Hemmer (1775), Johann Nast (1777), J.Ch. Adelung (1782), (cf. Jellinek 1914, II, §\$387-392). They discuss the distribution of the various case endings among name forms, also the treatment of foreign names where the article can serve to mark the case forms. The genitive ending $-e n s^{5}$ combines the strong ending $-s$ and the weak -en (gen. Boten); most grammars of the period define this $n$ as the suffixed article. This type of interpretation is facilitated by the fact that Latin grammarians do not recognize the article as a special part of speech.

The most influential and successful grammar of German in the 18th century was Johann Christoph Gottsched's Deutsche Sprachkunst (1748, ${ }^{1}$ $1749,{ }^{2} 1752,{ }^{3} 1757,{ }^{4} 1762^{5}$ ) also translated into French, and into Latin for use in Poland. He advocates inflecting foreign names, if morphologically possible, like German ones: thus Cäsar, gen. Cäsars, accus. Cäsarn; Alexander, gen. Alexanders, accus. Alexandern, etc. Like Martin Opitz in his Buch von der Deutschen Poeterey (1624) before him, Gottsched is against using Latin endings for Latin or foreign names; he prefers the use of the definite article to mark the cases. Thus he recommends (Gottsched 1762 , p. $467 f$.):

$\begin{array}{lrr}\text { nom. } & \text { Balbus } & \text { Phyllis } \\ \text { gen. } & \text { des Balbus } & \text { der Phyllis } \\ \text { dat. } & \text { dem Balbus } & \text { der Phyllis } \\ \text { accus. } & \text { den Balbus } & \text { die Phyllis } \\ \text { vocative } & \text { o Balbus } & \text { o Phyllis } \\ \text { ablative } & \text { vom Balbus } & \text { von der Phyllis }\end{array}$

He writes himself: des Confucius, des Dantes, des Petrarcha, des Clajus (also Clajs), in one case Taciti (p. 693) instead of des Tacitus; dem Cicero, den Homer, den Cotta.

Gottsched failed to include the declension of German names into his grammar. This made the Austrian J.S.V. Popowitsch, always a determined critic of Gottsched's grammar, use Gottsched's name in his own grammar (Popowitsch 1754): nominative Gottsched, gen. Gottscheds, dat. Gottscheden, acc. Gottscheden. This infuriated Gottsched who did not see anything complimentary in this use of his name by his opponent. He tried in vain to induce the Austrian authorities to censor Popowitsch's

\footnotetext{
${ }^{5}$ Aichinger (1754) who inflects der Name, des Namens, und das Herze, des Herzens otherwise considers -ens only suitable for personal names: Schwarzens, Hassens (from Hasse), Neuens (from $\mathrm{Neu}$ ) (Aichinger 1754, p. 217, 220).
} 
work but they refused to interfere in spite of Gottsched's excellent connections to the imperial court in Vienna.

Gottsched's use of case-endings for personal names can be observed in his books. We encounter the traditional differentiation between nominative, genitive, accusative. The only common nouns in Gottsched's grammar (1762, p. 283) which show three different case forms in the singular are the neuter das Herz (gen. -ens, dative -en) and the masculine der Schmerz 'pain,' which have, however, identical forms in nom. and accus.

Gottsched writes $-s$ in the genitive after most final consonants: Bessers, Goldasts, Königs, Luthers, Ottfrieds. After sibilants, but also after final $-e$ the ending is - $(e) n s$ : Baldens (from Balde), Brocksens (from Brockes), Kanitzens (from Kanitz), Omeisens (from Omeis), Pietschens (from Pietsch), Vossens (from Voß). Popens from Pope shows that Gottsched pronounced his name [po:pe]. ${ }^{6}$ The genitive -ens does not always clearly indicate the nominative: Heinzens could come from Heinze or Heinz. Thus, Gottsched (1762, p. 33) calls his opponent Johann Michael Heinze once "Herr Rector Heinz," and once the poet Hans Sachs Hans Sachse (p. 646).

Dative and accusative forms have the ending -en, or $-n$ after $-e r-$ : Flemmingen (from Flemming), Freinsheimen (from Freinsheim), Opitzen, Neukirchen, Ottfrieden, Sachsen, and Buchnern (from Buchner), Conrad Gesnern, Günthern, etc.

J.Ch. Adelung treats in his grammar (1782) inflection of personal names in detail; he maintains wrongly, however, that all previous grammars had neglected to treat this topic. To illustrate the variety of usage, he quotes for the personal name Wolf the following case-forms:

gen. Wolfs, Wolfens (common noun: Wolfes)

dative: Wolfen, dem Wolf (common noun: Wolfe)

accusative: Wolfen, den Wolf (Adelung 1782, I, p. 533 [\$241])

Jellinek (1914, II, p. 246) comments in effect: what is wrong with a genitive des Wolf?

\section{CONCLUDING REMARKS}

In our brief survey of the inflection of German personal nouns from Old High German to modern times we have found differences between their

\footnotetext{
${ }^{6}$ Gottsched's wife Louise Adelgunde Gottsched translated A. Pope's The Rape of the Lock into German (Leipzig 1744). Gottsched seemed oddly prejudiced against English as a language calling it "sehr roh und ungezieret" (Gottsched 1762, p. 63).
} 
declension and that of corresponding common nouns. The nominative of personal names is, in comparison to the inflected oblique cases, marked by a zero ending. In Old High German this even applied to foreign names, e.g. in Tatian's 9th century gospel harmony: Petrus, gen. Petruses, (Petres, Petri), dat. Petruse (Petre, Petro), acc. Petrusan (Petrum). In Middle High German, Early New High German, the 18th century, in the language of young Friedrich Schiller (Pfleiderer 1903) 7 weak and strong case endings of common noun desclensions were often combined to provide the maximal case distinction particularly important for personal names. Even contemporary German still shows some case distinctions not found with corresponding common nouns: Maries with masculine $-s$; Fritzens with its -ens, which is no longer in conversational use, however.

University of California, Berkeley

7In F. Schiller's (1759-1805) language genitives in -ens have become comparatively rare: beside Amaliens (from Amalia) he wrote meines Franzen, even seines Franzes (from Franz). Karl has the genitive Karls, dat., accus. Karln. - Wilmanns (1909) rejects -es instead of -s for the genitive, and finds the obsolete ("veraltet") -ens still acceptable for first names in -e: Elsens (p. 403). 


\section{BIBLIOGRAPHY}

Adelung, Johann Christoph. 1782. Umständliches Lehrgebäude der Deutschen Sprache. 2 vols. Leipzig, Breitkopf.

Aichinger, Carl Friedrich. 1754. Versuch einer teutschen Sprachlehre. (reprinted Hildesheim/New York, Olms, 1972)

Bach, Adolf. 1952. Deutsche Namenkunde. vol. 1.1

Baesecke, Georg, 1918. Einführung in das Althochdeutsche.

Braune, Wilhelm and Hans Eggers. 1975. Althochdeutsche Grammatik. 13th ed.

Duden. Grammatik der deutschen Gegenwartsprache. 1973. 3rd ed. by P. Grebe et al.

Franck, J. 1909. Altfränkische Grammatik.

Gottsched, Johann Christoph. 1762. Vollständigere und Neuerläuterte Deutsche Sprachkunst, ed. by Herbert Penzl (Ausgewählte Werke, vol. 8, parts 1-3) Berlin/New York, de Gruyter, 1978-1980.

Jellinek, Max Hermann. 1913-1914. Geschichte der neuhochdeutschen Grammatik von den Anfängen bis auf Adelung.

Kehrein, Joseph. 1854-1856. Grammatik der deutschen Sprache des fünfzehnten bis siebenzehnten Jahrhunderts. 3 parts (reprinted Hildesheim 1968).

Leys, Odo. 1966. "Der Eigenname in seinem formalen Verhältnis zum Appellativ". In: Beiträge zur Namenforschung 1966, pp. 113-123.

Müller-Fraureuth, Carl. 1895. Die deutsche Grammatik des Laurentius Albertus. (Ältere deutsche Grammatiken in Neudrucken III)

Paul, Hermann, Hugo Moser, and Ingeborg Schröbler. 1969. Mittelhochdeutsche Grammatik. 20th ed.

Penzl, Herbert. 1982. Frühneuhochdeutsch. Eine Einführung in die Sprache. (Germanistische Lehrbuchsammlung) Bern, P. Lang. forthcoming.

Pfleiderer, W. 1903. "Die Sprache des jungen Schiller in ihrem Verhältnis zur neuhochdeutschen Schriftsprache". In: Beiträge zur Geschichte der deutschen Sprache und Literatur 28, pp. 346ff.

Popowitsch, J.S.V. 1754. Die nothwendigsten Anfangsgründe der Teutschen Sprachkunst. Vienna.

Weidling, Friedrich. 1894. Die deutsche Grammatik des Johannes Clajus. (Ältere deutsche Grammatiken in Neudrucken II)

Wilmanns, W. 1909. Deutsche Grammatik. III. 2nd part. 